\title{
Galerina pruinatipes, a new species to the Nordic countries
}

\author{
GRO GULDEN and TEA VON BONSDORFF-SALMINEN
}

GULDEN, G. \& VON BONSDORFF-SALMINEN, T: 2006: Galerina pruinatipes, a new species to the Nordic countries. - Karstenia 46: 33-36. Helsinki. ISSN 0453-3402.

The rare or overlooked Galerina species G. pruinatipes A.H. Sm. is reported as new for northern Europe with two finds from Finland. The species is previously known only from rotting coniferous wood while the specimens of the two Finnish finds were growing on rotting wood of Alnus and Betula.

Gro Gulden, Natural History Museum, University of Oslo, P.O. Box 1172 Blindern, N-0318 Oslo, Norway

Tea von Bonsdorff-Salminen, Botanical Museum, P.O. Box 7, FI-00014 University of Helsinki, Finland

\section{Introduction}

During the 17th Nordic Mycological congress at Hyytiälä, S Finland the latter author found a small Gymnopilus-like fungus growing among moss on very decayed Alnus wood. A somewhat hairy-scurfy pileus brought to mind also the genus Flammulaster. However, a closer look at the spores revealed a distinct plage - a characteristic feature of the genus Galerina. The cystidia of this fungus were conspicuous with large heads (Fig. 1), more or less matching the term utriform, and they occurred as cheilo-, pleuro-, caulo- and pileocystidia. The specimens were readily identified as Galerina pruinatipes A.H.Sm. - a species belonging to sect. Physocystis A.H. Sm. of subg. Galerina. This is a quite particular Galerina species both with regard to the gross-morphology and anatomy. Outstanding field characters are found in the shape and colour of

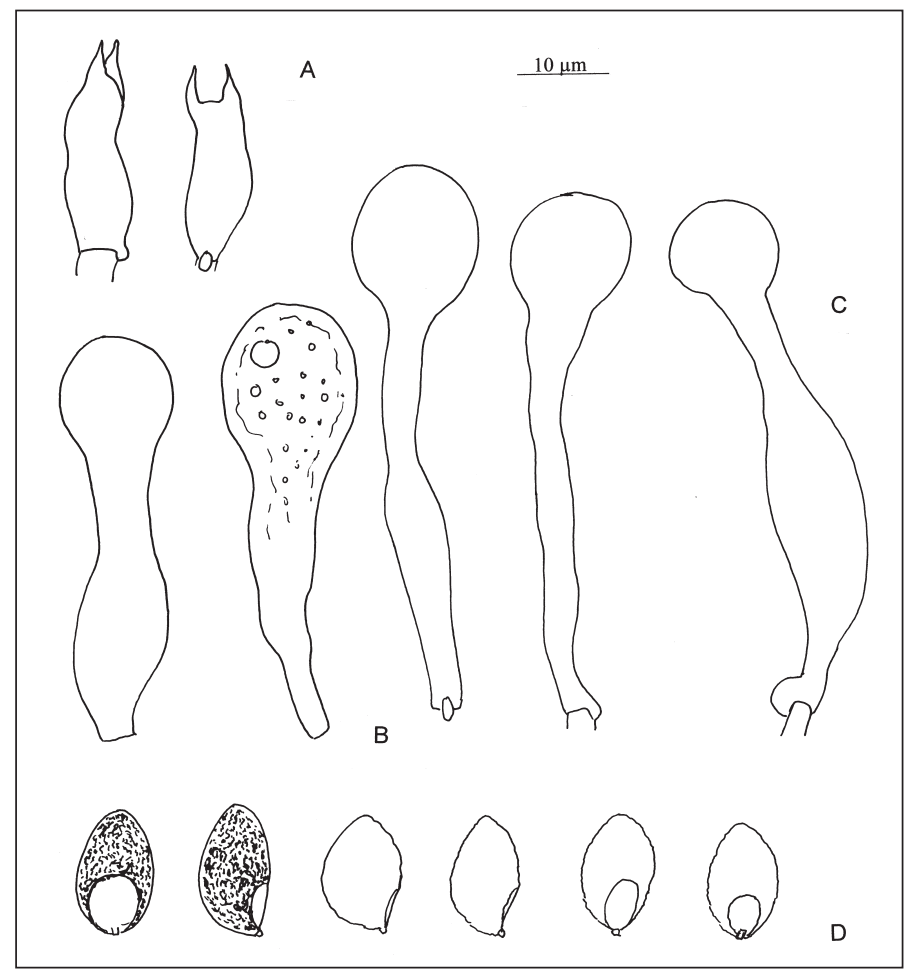

Fig 1. Galerina pruinatipes A.H. Sm., drawn in 5\% KOH. FINLAND: Etelä-Häme, Ruovesi GG 109/05 (O). A) Basidia, B) Cheilocystidia, C) Caulocystidium, D) Spores. 
the pileus and the stipe and in the taste, which is strongly bitter. The pileus is expanded (umbonate-convex to almost plane), tends to become pruinose to scurfy especially on drying, and the colour is reddish ochre to date-brown. The upper part of the stipe is coarsely pruinose and the base dark-brown.

The species has not been reported earlier from the Nordic countries, but Ilkka Kytövuori kindly provided us with one additional collection from northern Finland. Further south in Europe the species appears to be rare, or its typical kind of habitat, mountainous conifer forests with abundance of decaying wood, have been little investigated. The former of the authors has previously collected G. pruinatipes in France (in the mountains of Chartreuse (Isère) at $1280 \mathrm{~m}$ altitude). Recent descriptions and illustrations of $\mathrm{Ga}$ lerina pruinatipes can be found in Breitenbach and Kränzlin (2000) and Senn-Irlet (2005), but Breitenbach and Kränzlin have worked with a mixed collection: The fruitbodies shown in the plate 420 are of G. sahleri (Quél.) Kühner, while the accompanying illustration of anatomical features represents $G$. pruinatipes (Senn-Irlet 2005).

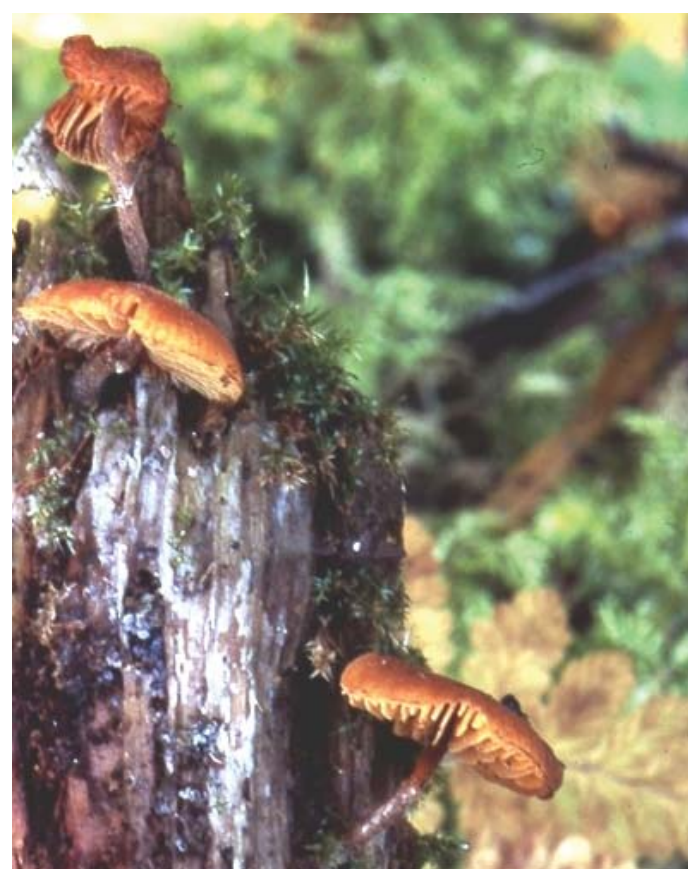

Fig. 2. Galerina pruinatipes A.H. Sm. FINLAND. EteläHäme, Ruovesi GG 109/05 (O). Photo Mauri Lahti.

\section{Description of the Finnish material}

Pileus up to $1.2 \mathrm{~cm}$, broad compared to the length of the stipe, convex, matt, somewhat scurfy-subscaly at centre, faintly translucently striate up to $1 / 2$ of the radius, warm yellow- brown to redbrown. Lamellae broadly adnexed-adnate, narrow, not ventricose, edge white fimbriate, pale beige to dull and rather dark yellow-brown. Stipe $50 \times 1 \mathrm{~mm}$, apex white pruinose, downwards with ochre to yellow-brown fibrils, becoming dark red-brown from the base upwards. Veil evanescent, seen as fibrils on stipe, no ring. Taste very bitter.

Spores $10.0-11.6 \times 6.1-7.7 \mu \mathrm{m}, \mathrm{Q}=1.5-1.7$ $(\mathrm{n}=32)$, amygdaliform, \pm attenuated at apex (with callus), verrucose or with cracked surface, leaving small ridges between cracks, plage distinct, tawny in KOH, dextrinoid. Basidia 19.2-26.5 $\times$ 5.0-7.2 $\mu \mathrm{m}$, small (esp. compared to the cystidia), 2-spored. Cheilo- and pleurocystidia present. Cheilocystidia crowded, 45.0-72.5 × 7.3-22.0 $\times$ $4.8-9.6 \times 8.0-25 \mu \mathrm{m}$, generally ventricose-capitate with distinctly delimitated head and a strangulation or a broad, short neck, also rather frequently without ventral inflation, rarely lageniform or cylindric, with narrow, hyphoid basal elongation, becoming \pm amber to tawny from oily-granulose content. Pleurocystidia scattered, corresponding in shape but often larger, with \pm brown content. Caulo- and pileocystidia corresponding to the hymenial cystidia but generally larger, often $>100$ $\mu \mathrm{m}$ long. Subhymenium of narrow, 2-3 $\mu \mathrm{m}$ wide hyphae; lamella trama of inflated and rather shortcelled, \pm brown hyphae. Stipitepellis of amber to red-brown rather narrow and short-celled hyphae, 2-7 $\mu \mathrm{m}$ wide. Pileipellis of inflated and rather short-celled hyphae, ca 8-40 $\mu \mathrm{m}$ wide. Clamps numerous in all tissues. Pigment incrusting. - Microscopical characters were observed in Melzer's reagent and in $5 \% \mathrm{KOH}$.

Specimens examined: FINLAND. Etelä-Häme: Ruovesi, along highway 66 at Ryövärinkuoppa, on rotting, very decayed Alnus glutinosa, 7.IX.2005 Tea von Bonsdorff GG 109/05 (O). Sompion Lappi: Sodankylä, in Urho Kekkonen National Park, Nattastunturit, SSW foot of PyhäNattanen, at the beginning of the footpath from the forest road, springy depression with spruce-hardwood swamp and Salix spp., on strongly decayed Betula wood, alt. 295 m, 23.VIII.1990 Kytövuori 90-599 (H). 


\section{Discussion}

Galerina pruinatipes (with two varieties) was originally described on the basis of four collections from mountainous regions in Pacific $\mathrm{N}$. America (Washington state), all from decaying conifer logs (Smith 1953). From Smith's descriptions we do not see any good reason for distinction between two varieties, but our material fits best the var. fulvipes A.H. Sm., characterized by \pm amber to yellow-brown cheilocystidia and yellow-brown to fulvous fibrils in the lower part of the stipe. Apparently, G. pruinatipes grows mainly in boreal and mountainous coniferous forests. Up to now it has only been found on coniferous wood (Larix, Picea), but the specimens collected in northern Finland grew on Betula and the one from southern Finland on Alnus.

Kühner (1966) was the first to record $G a$ lerina pruinatipes in Europe, from six places in the mountains of Haute-Savoie and near the Pyrenees. However, Kühner was of the opinion that the species had been reported in Europe earlier, but under other names. He argued that the fungus illustrated by Bresadola (1930, in pl. 785 as Flammula limulata Fr.) must have been $G$. pruinatipes - in spite of a somewhat ambiguous description, and he also considered the species Favre (1960) described as Gymnopilus laricicola identical. We have no difficulty in supporting the conclusions of Kühner - which also have been generally accepted.

Bon (1992), however, considered Galerina pruinatipes and Gymnopilus laricicola as different species, and he made the new combination Galerina laricicola (J. Favre) Bon, recognizing Favre's species as a Galerina. Just like Senn-Irlet (2005) we consider this view erroneous, based as it is on wrong suppositions.

There is disagreement and inaccuracy in the information on the taste of Galerina pruinatipes. Smith, Kühner, Bresadola and also the present authors convey that the species has a distinctly bitter taste and this is one of the outstanding field characters of the species, while Favre and Breitenbach and Kränzlin signalize a mild taste. That Favre described his Gymnopilus laricicola without smell and taste ("inodore, insipide") was dismissed by Kühner as more or less a habit of Favre, since he had also failed to recognize the farinaceous taste of $G$. rubiginosa (= G. vittiformis p.p.). We rather believe it has been a 'slip of the pen' since one of the best arguments for placing the species in the genus Gymnopilus is the bitter taste. However, it may also be a disability of Favre to sense a bitter taste. The quite strange indication of both a mild and a raphanoid taste by Breitenbach \& Kränzlin probably results from their mixed collection and the erroneous statement by Bon (1992) that G. pruinatipes according to Smith has a mild taste.

Smith and Singer (1958) placed Galerina pruinatipes in sect. Physocystis on account of the capitate and broad-necked (utriform) cheilo- and pleurocystidia. This is a small section of Galerina and apparently only four of its 13 species are known from the northern hemisphere and only two of them, G. pruinatipes and G. salicicola P.D. Orton, are known from Europe. These two are rather different since $G$. salicicola is a fairly robust species that lacks dermatocystidia and has 4 -spored basidia. Both species were included in a recent molecular study of Galerina (Gulden et al. 2005) that showed the genus Galerina to be polyphyletic with at least three or four separate lineages. In a phylogeny obtained from nuclear ribosomal LSU sequence data that included representatives of several brown-spored genera, $G$. pruinatipes appeared outside the main Galerina clades.

Although Galerina pruinatipes shows little anatomical similarity with the species of Gymnopilus, the two genera Galerina and Gymnopilus in general have many anatomical characters in common, including features of spores and cystidia in some groups (Kühner 1980). Especially many southern hemisphere species with tibiiform cystidia and plage on the spores are difficult to distribute between the two genera (Rees et al. 1999, 2002). The gross-morphology in the two genera is generally not very similar. While most Galerina species grow on bryophytes and have a mild or farinaceous taste, some, such as our $G$. pruinatipes and also G. badipes, have a bitter taste and a lignicolous habit, which are typical features of Gymnopilus. A strong connection between Galerina and Gymnopilus was found in the phylogenetic study by Gulden et al. (2005), but G. pruinatipes did not occur close to the Gymnopilus species included in the study. 
Acknowledgements: We thank Ilkka Kytövuori for providing us the specimen (90-599) and Tuuli Timonen and Pirkko Harju for identifying the substrate. We thank Anna-Elise Torkelsen for identifying the substrate of the specimen from Ruovesi (GG 109/05). Thanks are extended also to Mauri Lahti, who let us use his photo of $G$. pruinatipes.

\section{References}

Bon, M. 1992: Clé monographique des espèces galeronaucorioides. - Documents Mycologiques 21: 1-89.

Breitenbach, J. \& Kränzlin, F. 2000: Pilze der Schweiz 5. - Fred Kränzlin, Edition Mykologia, Lucerne. 338 pp.

Bresadola, J. 1930: Iconographia Mycologica 16. - Mediolani, Milano.

Favre, J. 1960: Catalogue descriptif des champignons supérieurs de la zone subalpine du Parc National Suisse. - Ergebnisse wissenschaftl. Untersuch. Schweiz. Nat. Park. 6: 1-610.

Gulden, G., Stensrud, Ø., Shalchian-Tabrizi, K. \& Kauserud, H. 2005: Galerina Earle: A polyphyletic genus in the consortium of dark-spored agarics. - Mycologia 97: 823-837.
Kühner, R. 1966: Galerina pruinatipes Smith (= Gymnopilus laricicola Favre). Espèce nouvelle pour la France. - Bull. Soc. Myc. France 82: 602-609.

Kühner, R. 1980: Les Hyménomycètes agaricoïdes (Agaricales, Tricholomatales, Pluteales, Russulales). Etude générale et classification. - Bull. Soc. Linn. Lyon 49, Num. spec. 1027 pp.

Rees, B. J., Orlovich D. A. \& Marks, P. B. D. 1999: Treading the fine line between small-statured Gymnopilus and excentrically stipitate Galerina species in Australia. - Mycol. Res. 103: 427-442.

Rees, B. J., Zuccarello, G. C. \& Orlovich, D.A. 2002: Relationships between Australian and northern hemisphere Gymnopilus species II. A preliminary phylogeny of species of Gymnopilus and related genera based on internal transcribed spacer (ITS) region of ribosomal DNA. - Mycotaxon 84: 93-110.

Senn-Irlet, B. 2005: Galerina pruinatipes A.H. Sm. (1953) Une espèce rare venant sur bois fortement dégradé dans les forêts alpines. - Schw. Zeitschr. Pilzk. 4: $148-150$.

Smith, A. H. 1953: New species of Galerina from North America. - Mycologia 45: 892-925.

Smith, A. H. \& Singer, R. 1958: The genus Galerina. An outline of its classification. - Sydowia 11: 446-453.

Smith, A. H. \& Singer, R. 1964: A monograph on the genus Galerina Earle. - Hafner Publ. Comp., New York and London. 384 pp. 